\title{
Kryteria i skutki uznania nieruchomości za zabytek
}

\section{Witold Werner}

\section{STRESZCZENIE}

Nieruchomości pełnią podstawową rolę służebną w stosunku do swoich właścicieli, którzy mają lub mogą mieć konkretne plany inwestycyjne związane z nieruchomością.

Poza znanymi już powszechnie ograniczeniami w egzekwowaniu prawa własności, sformułowanymi w ustawie o planowaniu i zagospodarowaniu przestrzennym, ustawie Prawo budowlane, $\mathrm{tzw}$. „specustawach" dotyczących przede wszystkim inwestycji drogowych, kolejowych i mieszkalnictwa oraz przepisach wykonawczych wydanych na podstawie tych ustaw, niedoceniane wydają się skutki wpisywania nieruchomości do rejestru zabytków bądź gminnej ewidencji zabytków.

Kontrowersyjne kwalifikowanie i wpisywanie nieruchomości do rejestru zabytków, bez wcześniejszego uprzedzenia, prowadzą do sytuacji, w której właściciel lub nabywca nieruchomości może być w każdym czasie zaskoczony uznaniem jej za zabytek, co ogranicza lub wyklucza realizacje planów inwestycyjnych.

Słowa kluczowe: plany inwestycyjne, prawo własności, kwalifikacje zabytków

\section{Zabytek w hierarchii potrzeb ludzkich}

Teorię hierarchii potrzeb ludzkich sformułowaną przez amerykańskiego psychologa A.H. Maslowa przedstawia się zazwyczaj w postaci równobocznego trójkąta (ściany piramidy) podzielonego poziomymi, równoległymi pasami. W najniższym pasie mieszczą się potrzeby fizjologiczne (Physiological Needs), w następnym pasie bezpieczeństwo (Safety), na trzecim piętrze potrzeby uznania i przynależności do określonej grupy (Love E Belonging), na czwartym uznania się szczęśliwym (Self-Esteem), a dopiero na szczycie - osiągnięcie możliwości samorealizacji (Self-Actualization).

Z konstrukcji tej piramidy wynika, że bez względu na obszar kuli ziemskiej, ustroje polityczne i stan gospodarki - najliczniejszą część społeczeństwa stanowią ludzie zajmujący najniższe poziomy w hierarchii potrzeb ludzkich i oni narzucają sposób sprawowania władzy, poprzez wymuszone na rządzących decyzje dotyczące ochrony środowiska naturalnego, jedynie w kontekście zapewnienia przestrzeni dla produkcji żywności oraz zamieszkania.

Na tle tej niepodważalnej teorii powstaje pytanie - na którym poziomie rozwoju społecznego powstała i powstaje potrzeba tworzenia i utrzymania szeroko rozumianej sztuki, np. w postaci malowideł na ścianach pierwotnych pieczar? Czy była to tylko dekoracja, czy też forma potwierdzenia aktualnej własności nieruchomości, z może już pierwszą formą przekazu sztuki dla następców, jako przyszły zabytek? 
Gwałtowny przyrost ludności na całym świecie powoduje konieczność tworzenia nowej przestrzeni do produkcji żywności, co zdaje się usprawiedliwiać naruszanie nawet takich chronionych dla dobra ludzkości przestrzeni, jak np. lasów w Ameryce Południowej, decydujących o klimacie w skali światowej. Decyzje w imię wyższych celów społecznych zmuszeni są podejmować ludzie stojący na wysokich stopniach hierarchii potrzeb ludzkich. Jest to też obiektywnie wskazane na konieczność umiaru „w kreowaniu” nowych zabytków ograniczających działania rozwojowe w każdej skali i wyważaniu racjonalnego salda strat i korzyści społecznych.

\section{Formy prawne ochrony zabytków}

Ustawa o ochronie zabytków i opiece nad zabytkami w sposób mało precyzyjny:

1. definiuje pojęcie zabytek, zakres ochrony i opieki nad zabytkiem oraz kryteria uznawania nieruchomości za zabytek, jak np. kryterium „stanowienia świadectwa minionej epoki";

2. określa metody postępowania administracji, dotyczące wpisywania nieruchomości do rejestru lub ewidencji zabytków;

3. ustala formy ochrony zabytków oraz rolę, jaką w ochronie zabytków ma pełnić ewidencja zabytków.

„Formami ochrony zabytków są:

1. wpis do rejestru zabytków;

a. wpis na Listę Skarbów Dziedzictwa;

2. uznanie za pomnik historii;

3. utworzenie parku kulturowego;

4. ustalenia ochrony $\mathrm{w}$ miejscowym planie zagospodarowania przestrzennego albo w decyzji o ustaleniu lokalizacji inwestycji celu publicznego, decyzji o warunkach zabudowy, decyzji o zezwoleniu na realizację inwestycji drogowej, decyzji o ustaleniu lokalizacji linii kolejowej lub decyzji o zezwoleniu na realizację inwestycji w zakresie lotniska użytku publicznego." [Art. 7 ustawy o ochronie zabytków i opiece nad zabytkami].

„Ewidencja zabytków jest podstawą do sporządzania programów opieki nad zabytkami przez województwa, powiaty i gminy." [Art. 21 ustawy o ochronie zabytków i opiece nad zabytkami].

Generalny Konserwator Zabytków prowadzi krajową ewidencję zabytków, a wojewódzki konserwator zabytków prowadzi wojewódzką ewidencję zabytków w formie kart ewidencyjnych zabytków znajdujących się na terenie województwa. [Art. 22 ust. 1 i 2 ustawy o ochronie zabytków i opiece nad zabytkami].

„Wójt (burmistrz, prezydent miasta) prowadzi gminną ewidencję zabytków w formie zbioru kart adresowych zabytków nieruchomych z terenu gminy. 
W gminnej ewidencji zabytków powinny być ujęte:

1. zabytki nieruchome wpisane do rejestru;

2. inne zabytki nieruchome znajdujące się w wojewódzkiej ewidencji zabytków;

3. inne zabytki nieruchome wyznaczone przez wójta (burmistrza, prezydenta miasta) w porozumieniu z wojewódzkim konserwatorem zabytków." [Art. 22 ust. 4 i 5 ustawy o ochronie zabytków i opiece nad zabytkami].

Do rejestru zabytków wpisuje się zabytek nieruchomy na podstawie decyzji wydanej przez wojewódzkiego konserwatora zabytków (WKZ) z urzędu lub na wniosek właściciela zabytku nieruchomego lub użytkownika wieczystego gruntu, na którym znajduje się zabytek nieruchomy. Informację o wszczęciu postępowania w sprawie wpisania zabytku do rejestru zabytków (RZ) oraz podjętej decyzji w tej sprawie przez WKZ przekazuje się niezwłocznie właściwemu staroście.

Wpis nieruchomości do gminnej ewidencji zabytków (GEZ), zbliżony w skutkach materialnych do wpisu do RZ, podlega wprawdzie kontroli sądowej, w tym także z punktu widzenia spełniania przez wpisany obiekt ustawowej definicji zabytku, co wymaga jednak potwierdzenia odpowiednią ekspertyzą lub badaniami. Istotna różnica konsekwencji tych wpisów ma natomiast miejsce w odniesieniu do informacji o dokonanym wpisie. Wpis do RZ dokonywany jest na podstawie decyzji administracyjnej, która musi być doręczona właścicielowi zabytku, natomiast wpis do GEZ nie wymaga decyzji administracyjnej i powiadomienia właściciela o dokonanym wpisie. Mimo formalnej jawności dokonanych wpisów w gminnej ewidencji, właściciele nieruchomości mogą nie wiedzieć o dokonanym wpisie i wynikających stąd konsekwencjach.

\section{Kryteria wpisu nieruchomości do rejestru lub ewidencji zabytków}

Konsekwencje wpisania nieruchomości do rejestru zabytków lub do gminnej ewidencji zabytków „w interesie społecznym” powinny być podejmowane w formie decyzji kolegialnych, konsultowanych z powoływanymi w tym celu o odpowiedniej randze radami naukowymi ds. zabytków, z udziałem architektów, historyków i socjologów oraz gospodarza terenu, na którym znajdują się obiekty potencjalnie spełniające kryteria zabytkowej nieruchomości, ponadto wymagają bliższego określenia „przedmiotu ochrony i opieki konserwatorskiej” oraz uściślenia pojęcia „bez względu na stan zachowania”.

Inicjatorami poszerzania rejestrów i ewidencji zabytków, z dobrymi intencjami, są najczęściej różnego rodzaju stowarzyszenia społeczne sympatyków określonej części miasta lub gminy, bądź ugrupowania o wyraźnej konweniencji politycznej, promujące miejsca związane z określonymi osobami, środowiskami lub wydarzeniami.

Przedmiotem takich inicjatyw może to być zatem wiekowa kamienica, ale też przeciętny dom jednorodzinny, uznany za zabytek ze względu na miejsce urodzin lub zamieszkania osoby o wątpliwej i zmiennej w czasie „wybitności” lub barak przemysłowy wyposażony w stare urządzenie techniczne, kwalifikujące się raczej do przeniesienia do muzeum techniki. 
Interesujące, przed kilku latami, było np. „społeczne” oczekiwanie na decyzję wpisania do rejestru zabytków Pałacu Kultury i Nauki w centrum Warszawy, po ukończeniu 50 lat jego istnienia, praktycznie zapobiegające jego wyburzeniu ze względów politycznych, jak też współcześnie wątpliwy pomysł wpisania do rejestru zabytków budownictwa z wielkiej płyty, również po 50 latach egzystencji tej postępowej wówczas techniki wznoszenia budynków.

Dotychczasowy tryb „wszczęcia postępowania w sprawie wpisania zabytku nieruchomego do rejestru", jak też usunięcia z tego zbioru - jednoosobową decyzją wojewódzkiego konserwatora zabytków, „przekazując niezwłocznie tę decyzję” staroście, świadczy o jedynowładztwie wojewódzkich konserwatorów oraz o zaskakującym pośpiechu przy podejmowaniu niektórych decyzji.

Interesującym przykładem z województwa mazowieckiego może być np. „porozumienie" mazowieckiego wojewódzkiego konserwatora ze stołecznym konserwatorem zabytków z dnia 7 listopada 2018 r. o „wskazaniu” 56 obiektów do włączenia do gminnej ewidencji zabytków m.st. Warszawy, 14 obiektów do wyłączenia, 15 obiektów do pozostawienia w ewidencji oraz kilku ze zmienionym zakresem ochrony.

\section{Skutki prawne i ekonomiczne uznania nieruchomości za zabytek}

Ustawa o ochronie zabytków i opiece nad zabytkami określa tryb wydawania pozwoleń na prowadzenie prac konserwatorskich, restauratorskich, robót budowlanych, badań konserwatorskich, badań architektonicznych i innych działań przy zabytkach wpisanych do rejestru zabytków oraz badań archeologicznych i poszukiwań zabytków.

Wyżej wymieniona ustawa i wydane na jej podstawie przepisy wykonawcze w praktyce „ubezwłasnowolniają” właścicieli nieruchomości wpisanych do rejestru zabytków lub ewidencji. Pomijając obiekty o stosunkowo mniejszym wpływie na wartość nieruchomości, jak np. ogrodzenia, kominy czy historyczna nawierzchnia ulicy, pozostałe obiekty, takie jak budynki, w tym z ogrodami, a także nieruchomości sąsiadujące z zabytkiem - tracą swoją wartość rynkową. Każda bowiem, nawet nieznaczna przebudowa lub remont, wymaga kłopotliwego przeprowadzania uzgodnień z właściwym miejscowo konserwatorem zabytków i związanych z tym kosztów.

Szczególnie dotkliwą dla właścicieli nieruchomości wpisanych do rejestru zabytków lub ewidencji jest sytuacja nieprzewidywalnego, pośpiesznego jej wpisania, zwłaszcza w przypadkach planowanego zamiaru inwestowania.

Oczywiście odwrotna sytuacja - wyłączenia nieruchomości z tego wykazu oznacza w praktyce wzrost wartości takiej nieruchomości, choć nie wyklucza możliwości zmiany stanowiska, np. przy wystąpieniu o uzyskanie warunków zabudowy, pozwolenia na budowę lub rozbiórkę.

Konsekwencje wpisów zarówno do RZ, jak i GEZ podlegają wprawdzie kontroli sądowej, jednak wątpliwości wojewódzkich sądów administracyjnych w orzeczeniach dotyczą- 
cych ochrony prawnej właścicieli nieruchomości, skłoniły Naczelny Sąd Administracyjny do dalej cytowanego pytania prawnego w formie „Postanowienia”, w którego uzasadnieniu wymienione zostały m.in. następujące powtarzające się problemy (oparte na przykładzie konkretnej nieruchomości):

- $\quad$ wattpliwości, co do zgodności ograniczenia prawa własności nieruchomości z Konstytucją RP oraz prawem międzynarodowym w wyniku ujęcia nieruchomości jako zabytku w GEZ, bez zapewnienia właścicielowi gwarancji ochrony procesowej i materialnej;

- włączenia nieruchomości do GEZ bez postępowania zmierzającego do ustalenia i oceny jego wartości historycznych lub artystycznych oraz stanu zachowania;

- $\quad$ przepisów nieprzewidujących zawiadomienia właściciela, że nieruchomość została włączona do GEZ;

- dopuszczenie ograniczenia prawa własności, w ramach uproszczonej procedury o charakterze wewnętrznym, bez udziału właściciela w jakichkolwiek czynnościach postępowania administracyjnego;

- osłabienia ochrony własności poprzez „ukrywanie” przed właścicielem informacji o działaniach władzy, skutkujących ograniczeniem własności;

- $\quad$ powstania obowiązku uzgadniania z WKZ decyzji o warunkach zabudowy oraz pozwoleniu na budowę wg wymogów ustawy o planowaniu i zagospodarowaniu przestrzennym oraz ustawy Prawo budowlane. Uznanie wątpliwości prawnych NSA przez Trybunał Konstytucyjny za zasadne, w kontekście przepisów Konstytucji, dawałoby podstawę prawną właścicielom nieruchomości włączonych do ewidencji zabytków o odszkodowanie od Skarbu Państwa na podstawie tzw. deliktu legislacyjnego.

Niezależnie jednak od wyroku Trybunału Konstytucyjnego, „wysoka dynamika wzrostu ilości zabytków", wymaga pilnej korekty ustawy o ochronie zabytków i opiece nad zabytkami, uwzględniającej ww. uwagi NSA. Wymaga ponadto zmiany ustawy o księgach wieczystych, w których uznanie nieruchomości za zabytek powinno być wpisane do III części księgi wieczystej.

Poniżej treść pytania prawnego Postanowienia Naczelnego Sądu Administracyjnego z dnia 13 czerwca 2018 r.: „na podstawie art. 193 Konstytucji Rzeczypospolitej Polskiej [Dz.U. nr 76, poz. 483 ze zm.] przedstawić Trybunałowi Konstytucyjnemu następujące pytanie prawne:

„Czy art. 22 ust. 5 pkt 3 ustawy z dnia 23 lipca 2003 r. o ochronie zabytków i opiece nad zabytkami [Dz.U. z 2017 r. poz. 2187 ze zm.] w zakresie w jakim ogranicza prawo własności nieruchomości poprzez dopuszczenie ujęcia nieruchomości jako zabytku nieruchomego w gminnej ewidencji zabytków, bez zapewnienia właścicielowi gwarancji ochrony prawnej przed dokonaniem takiego ograniczenia, jest zgodny z art. 64 ust. 1 i ust. 2 w związku z art. 31 ust. 3 Konstytucji Rzeczypospolitej Polskiej z dnia 2 kwietnia 1997 r. oraz z art. 1 Protoko-łu nr 1 do Konwencji o ochronie praw człowieka i podstawowych wolności z dnia 20 marca 1992 r. [Dz.U. z 1995 r. Nr 36, poz. 175 ze zm.]". 


\section{Materiały źródłowe}

Maslow A.H., 1943, A Theory of Human Motivation, Psychological Review, 50, 4, s. 370-396.

Ustawa z dnia 7 lipca 1994 r. Prawo budowlane, tj. z dnia 21 maja 2019 r. (Dz.U. z 2019 r. poz. 1186).

Ustawa z dnia 27 marca 2003 r. o planowaniu i zagospodarowaniu przestrzennym, tj. z dnia 6 lutego 2020 r. (Dz.U. z 2020 r. poz. 293).

Ustawa z dnia 23 lipca 2003 r. o ochronie zabytków i opiece nad zabytkami:

1. w wersji opublikowanej w Dz.U. z 2017 r. poz. 2187 ze zm.;

2. tekst jednolity z dnia 6 lutego 2020 r. (Dz.U. z 2020 r. poz. 282).

\section{Criteria and effects of declaring a building as a historical landmark}

\section{ABSTRACT}

Real estate perform basic service for its owners who have or may have specific investment plans related to their property. The commonly known restrictions in the enforcement of property rights are formulated in the acts on spatial planning, construction law, as well as in the "special acts" regarding road, railway and housing investments. In addition, the effects of "adding" real estate to the national or municipal heritage registers, seem to be underestimated.

Controversial qualification and adding real estates to the heritage register without prior notice (vacation legis) may lead to a situation, in which the owner or buyer of a property may be at any time surprised by its gaining historical landmark status, thus limiting or excluding the implementation of any development plans.

Key words: investments plans, property rights, landmarks criteria

\footnotetext{
$\overline{\text { Witold Werner, }}$ prof. dr hab. arch., prof. zw. w WSEiZ, em. prof. PW, specjalizuje się w procedurach inwestycyjno-budowlanych, członek honorowy TNOiK i Sekcji Inżynierii Przedsięwzięć Budowlanych Komitetu Inżynierii Lądowej i Wodnej PAN.

Kontakt do autora: „Doradztwo Inwestycyjne Witold Werner", ul. Dzika 19/23/90, 00-172 Warszawa;

e-mail:witold.werner@wp.pl

Witold Werner, professor arch. PhD, Ordinary Professor of the University of Ecology and Management, professor emeritus of the Warsaw University of Technology, member of honor TNOIK.

Contact to the author:"Investment Advice Witold Werner", ul. Dzika 19/23/90, 00-172 Warszawa;

e-mail:witold.werner@wp.pl
} 